\title{
Short communication: Refinement of genetic regions associated with Mycobacterium avium subspecies paratuberculosis tissue infection and tolerance to Johne's disease
}

\author{
R. Zanella, ${ }^{*}$ R. H. Whitlock, $†$ and H. L. Neibergs ${ }^{* 1}$ \\ *Department of Animal Sciences, Washington State University, Pullman 99164-6353 \\ †Department of Clinical Studies-New Bolton Center, School of Veterinary Medicine, University of Pennsylvania, Kennett Square 19348
}

\begin{abstract}
Johne's disease is a highly transmissible bacterial disease caused by Mycobacterium avium ssp. paratuberculosis (MAP). The objective of this study was to refine the locus associated with MAP tissue infection and the locus associated with tolerance to Johne's disease. Using a genome-wide association analysis, single nucleotide polymorphisms associated with MAP tissue infection and tolerance to Johne's disease on Bos taurus autosome (BTA)3 and BTA15, respectively, have previously been identified. A 235-kb region on BTA3 was evaluated with 42 single nucleotide polymorphisms, and a 193-kb region on BTA15 was evaluated with 54 single nucleotide polymorphisms in a group of $209 \mathrm{Hol}-$ stein cows. Using a single marker association analysis and haplotype tests, we refined a region of $10.6 \mathrm{~kb}$ on BTA3 as being associated with MAP tissue infection and a region of $6.5 \mathrm{~kb}$ on BTA15 as being associated with tolerance to Johne's disease.
\end{abstract}

Key words: Johne's disease, genetic association

\section{Short Communication}

Johne's disease (bovine paratuberculosis) is a chronic, incurable, bacterial disease of ruminants caused by Mycobacterium avium ssp. paratuberculosis (MAP; Buergelt et al., 1978; Gonzalez et al., 2005). The fecaloral route is the major mode of transmission; however, fetal infection has also been observed (Seitz et al., 1989; Sweeney et al., 1992a,b). In the dairy industry, Johne's disease is responsible for substantial economic losses due to premature culling and reduced production (Nordlund et al., 1996; Johnson-Ifearulundu et al., 2000; USDA, 2008). Johne's disease has increased in prevalence in the United States over the last few decades. In $1996,21 \%$ of US dairy herds had one or more animals infected with MAP; in 2007, the number of herds with

Received January 19, 2011.

Accepted April 19, 2011.

${ }^{1}$ Corresponding author: neibergs@wsu.edu
Johne's disease had increased to 68\% (NAHMS, 1997; USDA, 2008).

Animals exposed to a pathogen may defend themselves through mechanisms of resistance or tolerance. Susceptibility has been defined as the likelihood of an animal to become infected by a pathogen (Raberg et al., 2007). Susceptibility to Johne's disease has been measured by MAP tissue infection of the animal (Settles et al., 2009). Infection leads to an inflammatory response at the host level initiating an antagonistic interaction between the host and pathogen (Stecher and Hardt, 2008). Tolerance has been defined as the ability of an animal to limit the severity of the infection caused by the pathogen (Raberg et al., 2007; Zanella et al., 2011). Tolerance to Johne's disease measures the relationship between infection intensity (level of MAP in the tissues) and fitness (level of MAP fecal shedding; Zanella et al., 2011). Susceptibility to Johne's disease has been classified as a categorical trait, whereas tolerance to Johne's disease has been measured as a quantitative trait. The quantitative estimation of tolerance to Johne's disease was computed using the peak levels of MAP fecal shedding and the peak levels of MAP tissue infection as described previously (Zanella et al., 2011). The effectiveness of selecting for animals that are less susceptible or tolerant to Johne's disease is unknown. The need exists to evaluate further the potential for selection of animals that are less susceptible to MAP tissue infection or are tolerant to Johne's disease. It was the objective of this study to refine the locus on BTA3 associated with MAP tissue infection and the locus on BTA15 associated with tolerance to Johne's disease in Holstein cattle. This study was approved by the Washington State University Institutional Animal Care and Use Committee, Office of Research Assurances.

The animals used for fine mapping in this study were the same as those used for the initial genomewide association analysis described previously (Settles et al., 2009; Neibergs et al., 2010; Zanella et al., 2011). Briefly, tissue and fecal samples from 245 Holstein cows from 4 dairy herds located in the eastern United States were harvested at slaughter and cultured for the pres- 
ence of MAP (Whitlock et al., 1996, 2000; Pradhan et al., 2009). To determine if the animals were MAP tissue infected or were shedding MAP in the feces, the presence of MAP was detected by cultures prepared from tissue taken from the ileum, ileo-cecal valve, and 2 adjacent ileo-cecal lymph nodes and from fecal samples collected at the time of slaughter using the method described by Whitlock et al. (1996). Samples with counts (cfu) of MAP $>0$ were classified as MAP infected. After genotyping and filtering for quality control, 90 animals were classified as MAP tissue infected (cases), and 119 animals were classified as MAP tissue negative (controls), regardless of their fecal culture status (Settles et al., 2009). None of the animals in this study were related as determined by their pedigrees or through identity-by-descent analysis. The phenotypic classification of MAP tissue infection was chosen because this phenotype had the strongest evidence $\left(P=3 \times 10^{-7}\right)$ for an association with MAP tissue infection and BTA3 (Settles et al., 2009).

Tolerance to Johne's disease was defined as the inverse relationship between fitness (measured by MAP fecal shedding) and infection intensity (measured by the level of MAP tissue infection). For peak fecal values, the greatest value of 4 culture tubes from 1 fecal sample was used for each animal. The peak tissue value was represented by the greatest count (cfu) for 1 of the 4 tissues evaluated. The quantitative measurement of tolerance to Johne's disease was calculated using the ratio of MAP peak counts cultured from fecal material and tissue samples as described previously (Zanella et al., 2011). This measure of tolerance was used as it provided the strongest evidence for an association $(P=1.1$ $\times 10^{-7}$ ) with tolerance to Johne's disease and BTA15 (Zanella et al., 2011). All animals that were measured for tolerance were MAP tissue positive.

Genotyping data were assessed for quality before the association analysis. An animal's genotyping data were removed from the analysis when more than $10 \%$ of the genotypes failed. This resulted in the removal of genotyping data of 5 animals ( 2 cases and 3 controls) from the MAP tissue infection analysis, leaving 88 cases and 116 controls. For the fine mapping of tolerance, the removal of 2 cases resulted in a total of 87 animals evaluated.

A custom 96-SNP assay (Illumina, San Diego, CA) was designed for the genotyping of the regions on BTA3 and BTA15. Single nucleotide polymorphisms were identified through dbSNP (http://www.ncbi.nlm.nih. gov/projects/SNP) and were chosen based on a lack of repetitive regions surrounding the SNP, their nucleotide location based on the Btau_4.0 assembly, SNP with high minor allele frequency (MAF), whether the SNP had been validated (if they had not been validated,
SNP with confirmation of sequence variation in more than one breed were preferred), and through the selection of sequences with scores $>70$ utilizing the Illumina assay design tool (Liu et al., 2009; National Center for Biotechnology Information, 2010). On BTA3, 42 SNP were chosen to cover a $235-\mathrm{kb}$ region $(111,586,713$ to $111,821,915 \mathrm{bp}$ ), with a median spacing of $2.3 \mathrm{~kb}$. On BTA15, 54 SNP were used to cover a 194-kb region $(21,155,914$ to $21,349,505 \mathrm{bp})$, with a median spacing of $3.0 \mathrm{~kb}$. Physical positions at each SNP were expressed relative to the forward strand of the reference genome (Table 1; Liu et al., 2009).

Single nucleotide polymorphisms were also assessed for quality before the association analysis. Single nucleotide polymorphisms were removed if MAF was less than $2 \%$, if the SNP failed to genotype in more than $10 \%$ of the samples, or if the SNP failed the HardyWeinberg equilibrium test $(P<0.001)$. Eighteen SNP on BTA3 had low MAF and 2 SNP failed the HardyWeinberg equilibrium test and were therefore removed from the analysis (Table 1). On BTA15, 8 SNP were removed due to low MAF, 3 SNP failed the HardyWeinberg equilibrium test, and 5 SNP had genotyping failure in more than $10 \%$ of the samples. Four SNP failed for more than one reason, resulting in $12 \mathrm{SNP}$ excluded on BTA15 (Table 1). After excluding poor quality SNP, 22 SNP with a median spacing of $3.3 \mathrm{~kb}$ remained for the fine mapping of MAP tissue infection on BTA3, and $42 \mathrm{SNP}$ with a median spacing of $3.5 \mathrm{~kb}$ remained for the fine mapping of tolerance on BTA15.

Statistical analysis was conducted with PLINK (version 1.07; Purcell et al., 2007). A chi-squared test was used to test for an association of MAP tissue infection with BTA3, and the Wald test was used to test for an association with tolerance to Johne's disease and BTA15. A significance threshold for the association analysis was set at $P<0.05$ after a chromosome-wide Bonferroni correction for multiple testing. A haplotype analysis was also performed with PLINK to identify if a haplotype was more informative than a single SNP in refining the association on BTA3 with MAP tissue infection and BTA15 with tolerance to Johne's disease. For each chromosome, an omnibus association statistic was performed to identify the overall association of the haplotype. If a significant association was identified, a haplotype-specific analysis was performed to determine which haplotype had the strongest evidence for an association with MAP tissue infection and tolerance to Johne's disease. Using the most significant haplotype blocks constructed within the region associated with the tolerance and MAP tissue infection, a multiple SNP analysis using a backward-elimination method was performed. In this method, individual SNP were first removed and the association retested, and then combi- 
Table 1. Single nucleotide polymorphisms used to refine the loci associated with Mycobacterium avium ssp. paratuberculosis (MAP) tissue infection on BTA3 and tolerance to Johne's disease on BTA15

\begin{tabular}{|c|c|c|c|c|c|}
\hline BTA & $\mathrm{SNP}^{1}$ & $\begin{array}{l}\text { Position } \\
(\mathrm{bp})^{2}\end{array}$ & Allele $1^{3}$ & Allele $2^{4}$ & $\mathrm{MAF}^{5}$ \\
\hline 3 & ss86339534 & $111,586,713$ & G & A & 0.118 \\
\hline 3 & rs43364348 & $111,587,151$ & $\mathrm{C}$ & G & 0.289 \\
\hline 3 & rs43364349 & $111,587,319$ & G & A & 0.468 \\
\hline 3 & rs43364352 & $111,595,322$ & A & $\mathrm{C}$ & 0.447 \\
\hline 3 & rs43364355 & $111,596,158$ & $\mathrm{~A}$ & G & 0.043 \\
\hline 3 & rs43364358 & $111,597,507$ & A & G & 0.229 \\
\hline 3 & rs43364359 & $111,597,612$ & $\mathrm{C}$ & G & 0.264 \\
\hline 3 & rs43364360 & $111,600,042$ & A & G & 0.043 \\
\hline 3 & rs43364362 $2^{6}$ & $111,602,315$ & $\mathrm{~A}$ & $\mathrm{C}$ & 0.251 \\
\hline 3 & $r s 43364365^{7}$ & $111,603,691$ & $\mathrm{~T}$ & $\mathrm{C}$ & 0.000 \\
\hline 3 & rs43364366 & $111,603,963$ & $\mathrm{~A}$ & G & 0.043 \\
\hline 3 & rs43364367 & $111,604,038$ & $\mathrm{~A}$ & $\mathrm{G}$ & 0.354 \\
\hline 3 & $r s 43364368^{7}$ & $111,604,478$ & $\mathrm{~A}$ & $\mathrm{C}$ & 0.000 \\
\hline 3 & rs43364369 & $111,605,185$ & $\mathrm{~A}$ & $\mathrm{G}$ & 0.154 \\
\hline 3 & rs43364370 & $111,606,780$ & $\mathrm{~T}$ & $\mathrm{C}$ & 0.446 \\
\hline 3 & rs43363223 & $111,607,985$ & $\mathrm{C}$ & $\mathrm{A}$ & 0.488 \\
\hline 3 & $r s 43363224^{7}$ & $111,608,284$ & G & $\mathrm{A}$ & 0.004 \\
\hline 3 & $r s 43363226^{7}$ & $111,609,910$ & $\mathrm{~T}$ & A & 0.004 \\
\hline 3 & rs43363227 & $111,610,137$ & $\mathrm{C}$ & G & 0.317 \\
\hline 3 & rs43363228 & $111,611,772$ & $\mathrm{~T}$ & G & 0.497 \\
\hline 3 & rs43364331 & $111,615,363$ & $\mathrm{~T}$ & $\mathrm{C}$ & 0.151 \\
\hline 3 & $r s 43364333^{7}$ & $111,619,177$ & $\mathrm{~T}$ & $\mathrm{C}$ & 0.000 \\
\hline 3 & ss86284409 & $111,623,092$ & $\mathrm{G}$ & $\mathrm{A}$ & 0.451 \\
\hline 3 & $r s 43364335^{7}$ & $111,624,024$ & $\mathrm{~T}$ & $\mathrm{C}$ & 0.002 \\
\hline 3 & $r s 43364337^{7}$ & $111,626,912$ & $\mathrm{~T}$ & $\mathrm{C}$ & 0.002 \\
\hline 3 & rs43364338 & $111,630,181$ & $\mathrm{C}$ & G & 0.004 \\
\hline 3 & rs43364339 & $111,638,517$ & A & $\mathrm{C}$ & 0.210 \\
\hline 3 & rs43364342 & $111,650,486$ & $\mathrm{~A}$ & $\mathrm{~T}$ & 0.211 \\
\hline 3 & rs43364344 & $111,658,290$ & $\mathrm{~T}$ & $\mathrm{C}$ & 0.000 \\
\hline 3 & $r s 43364345^{7}$ & $111,659,259$ & $\mathrm{~A}$ & $\mathrm{C}$ & 0.000 \\
\hline 3 & rs43363222 & $111,672,481$ & $\mathrm{~A}$ & $\mathrm{G}$ & 0.214 \\
\hline 3 & $r s 43363220^{7}$ & $111,679,242$ & A & $\mathrm{C}$ & 0.002 \\
\hline 3 & ss86341066 & $111,682,510$ & $\mathrm{~A}$ & $\mathrm{C}$ & 0.403 \\
\hline 3 & rs43363219 & $111,685,607$ & $\mathrm{~T}$ & G & 0.002 \\
\hline 3 & rs433632187 & $111,685,833$ & $\mathrm{~T}$ & $\mathrm{C}$ & 0.004 \\
\hline 3 & rs433632177 & $111,686,749$ & $\mathrm{C}$ & G & 0.004 \\
\hline 3 & $r s 43363216^{7}$ & $111,690,246$ & $\mathrm{~T}$ & $\mathrm{C}$ & 0.000 \\
\hline 3 & rs43363215 & $111,693,185$ & $\mathrm{~A}$ & $\mathrm{G}$ & 0.129 \\
\hline 3 & rs43361040 & $111,772,066$ & $\mathrm{~T}$ & $\mathrm{C}$ & 0.000 \\
\hline 3 & rs $43361042^{7}$ & $111,780,147$ & $\mathrm{~A}$ & $\mathrm{G}$ & 0.000 \\
\hline 3 & rs43361039 & $111,783,711$ & $\mathrm{C}$ & $\mathrm{A}$ & 0.002 \\
\hline 3 & ss86321724 & $111,821,915$ & $\mathrm{~T}$ & G & 0.287 \\
\hline 15 & rs417475r77 & $21,155,914$ & A & G & 0.195 \\
\hline 15 & rs41747580 6,7 & $21,157,418$ & $\mathrm{~T}$ & $\mathrm{~A}$ & 0.014 \\
\hline 15 & $r s 41747581$ & $21,158,813$ & $\mathrm{~T}$ & $\mathrm{~A}$ & 0.301 \\
\hline 15 & rs41747586 & $21,163,500$ & G & A & 0.233 \\
\hline 15 & rs41746819 & $21,170,784$ & $\mathrm{~A}$ & $\mathrm{~T}$ & 0.343 \\
\hline 15 & rs41746814 & $21,175,163$ & G & $\mathrm{A}$ & 0.372 \\
\hline 15 & rs41746792 & $21,179,818$ & $\mathrm{G}$ & A & 0.135 \\
\hline 15 & rs41746789 & $21,181,254$ & $\mathrm{~T}$ & $\mathrm{C}$ & 0.033 \\
\hline 15 & rs43201145 & $21,182,910$ & $\mathrm{~A}$ & $\mathrm{~T}$ & 0.016 \\
\hline 15 & rs41746787 & $21,186,596$ & $\mathrm{G}$ & $\mathrm{A}$ & 0.137 \\
\hline 15 & rs417466785 & $21,187,535$ & $\mathrm{C}$ & $\mathrm{T}$ & 0.137 \\
\hline 15 & $r s 41746783$ & $21,189,338$ & A & G & 0.021 \\
\hline 15 & $r s 41746762$ & $21,196,312$ & $\mathrm{~T}$ & $\mathrm{C}$ & 0.021 \\
\hline 15 & rs 41746759 & $21,199,060$ & $\mathrm{~A}$ & $\mathrm{C}$ & 0.024 \\
\hline 15 & rs 41746757 & $21,200,628$ & $\mathrm{~T}$ & $\mathrm{C}$ & 0.134 \\
\hline 15 & rs 41746756 & $21,202,180$ & $\mathrm{~T}$ & $\mathrm{~A}$ & 0.134 \\
\hline 15 & rs $41746753^{7,8}$ & $21,205,312$ & A & G & 0.000 \\
\hline 15 & rs $41746748^{8}$ & $21,209,294$ & $\mathrm{~A}$ & G & 0.181 \\
\hline 15 & rs 41746747 & $21,212,440$ & $\mathrm{C}$ & $\mathrm{T}$ & 0.031 \\
\hline 15 & rs417466743 & $21,214,982$ & G & $\mathrm{A}$ & 0.031 \\
\hline 15 & $r s 41746741$ & $21,217,235$ & $\mathrm{C}$ & $\mathrm{G}$ & 0.021 \\
\hline 15 & $r s 41746739$ & $21,220,611$ & $\mathrm{C}$ & G & 0.060 \\
\hline
\end{tabular}

Continued 
Table 1 (Continued). Single nucleotide polymorphisms used to refine the loci associated with Mycobacterium avium ssp. paratuberculosis (MAP) tissue infection on BTA3 and tolerance to Johne's disease on BTA15

\begin{tabular}{|c|c|c|c|c|c|}
\hline BTA & $\mathrm{SNP}^{1}$ & $\begin{array}{l}\text { Position } \\
(\mathrm{bp})^{2}\end{array}$ & Allele $1^{3}$ & Allele $2^{4}$ & $\mathrm{MAF}^{5}$ \\
\hline 15 & rs41746737 & $21,224,197$ & $\mathrm{C}$ & G & 0.156 \\
\hline 15 & $r s 41745722$ & $21,228,547$ & $\mathrm{~T}$ & $\mathrm{C}$ & 0.375 \\
\hline 15 & rs41745716 & $21,235,084$ & $\mathrm{~T}$ & $\mathrm{C}$ & 0.149 \\
\hline 15 & $r s 41745713^{7}$ & $21,236,954$ & $\mathrm{C}$ & A & 0.004 \\
\hline 15 & $r s 41745710^{7}$ & $21,242,632$ & $\mathrm{~A}$ & G & 0.007 \\
\hline 15 & $r s 41748392$ & $21,251,461$ & G & $\mathrm{A}$ & 0.454 \\
\hline 15 & $r s 41748407$ & $21,253,408$ & $\mathrm{~T}$ & $\mathrm{C}$ & 0.101 \\
\hline 15 & rs41748401 & $21,257,974$ & $\mathrm{~T}$ & $\mathrm{C}$ & 0.147 \\
\hline 15 & $r s 41748400$ & $21,260,261$ & $\mathrm{C}$ & G & 0.152 \\
\hline 15 & rs41748395 & $21,262,642$ & $\mathrm{~T}$ & $\mathrm{C}$ & 0.283 \\
\hline 15 & $r s 41748410$ & $21,263,976$ & $\mathrm{~T}$ & $\mathrm{C}$ & 0.318 \\
\hline 15 & rs41748412 & $21,270,896$ & A & G & 0.320 \\
\hline 15 & rs41748414 ${ }^{6}$ & $21,275,277$ & $\mathrm{~A}$ & G & 0.370 \\
\hline 15 & $r s 41749247$ & $21,276,876$ & $\mathrm{~T}$ & $\mathrm{C}$ & 0.146 \\
\hline 15 & rs41749241 & $21,280,720$ & G & $\mathrm{C}$ & 0.139 \\
\hline 15 & rs41749235 & $21,283,665$ & $\mathrm{~T}$ & $\mathrm{C}$ & 0.151 \\
\hline 15 & $r s 41748422$ & $21,288,468$ & $\mathrm{~T}$ & G & 0.342 \\
\hline 15 & rs41748420 & $21,289,813$ & G & A & 0.156 \\
\hline 15 & $r s 41748415$ & $21,295,290$ & $\mathrm{C}$ & $\mathrm{T}$ & 0.322 \\
\hline 15 & rs41749248 & $21,306,676$ & A & G & 0.079 \\
\hline 15 & rs41749249 & $21,311,151$ & $\mathrm{~T}$ & $\mathrm{C}$ & 0.077 \\
\hline 15 & rs417492506,8 & $21,313,152$ & G & A & 0.026 \\
\hline 15 & rs41749253 & $21,316,588$ & G & A & 0.290 \\
\hline 15 & rs41749254,8 & $21,317,982$ & $\mathrm{~A}$ & $\mathrm{C}$ & 0.016 \\
\hline 15 & $r s 41749267^{7}$ & $21,332,723$ & G & $\mathrm{C}$ & 0.000 \\
\hline 15 & $r s 41749265$ & $21,333,766$ & A & $\mathrm{T}$ & 0.131 \\
\hline 15 & rs41749264 & $21,335,803$ & $\mathrm{~T}$ & C & 0.266 \\
\hline 15 & $r s 41749261$ & $21,337,533$ & A & G & 0.135 \\
\hline 15 & rs $41749270^{7}$ & $21,342,547$ & $\mathrm{C}$ & $\mathrm{A}$ & 0.000 \\
\hline 15 & rs41749273 & $21,344,763$ & $\mathrm{C}$ & $\mathrm{T}$ & 0.454 \\
\hline 15 & $r s 41749274$ & $21,347,820$ & A & G & 0.449 \\
\hline 15 & rs41749275 & $21,349,505$ & G & A & 0.197 \\
\hline
\end{tabular}

${ }^{1}$ GenBank accession number for the SNP (http://www.ncbi.nlm.nih.gov/projects/SNP).

${ }^{2}$ Location of the SNP on the chromosome based on Btau_4.0 (Liu et al., 2009).

${ }^{3}$ Allele with lowest frequency observed when cases and controls were combined.

${ }^{4}$ Allele with greatest frequency observed when cases and controls were combined.

${ }^{5}$ Minor allele frequency: frequency of the allele with the lowest frequency observed when cases and controls were combined.

${ }^{6} \mathrm{SNP}$ that were excluded due to lack of Hardy Weinberg equilibrium $(P<0.001)$.

${ }^{7} \mathrm{SNP}$ that were excluded due to minor allele frequency $<0.01$.

${ }^{8} \mathrm{SNP}$ that were excluded because more than $10 \%$ of the genotypes were missing.

nations of SNP were included and excluded manually from each haplotype block using PLINK to define the region associated with each phenotype.

Within the 235-kb region tested on BTA3, 2 loci located $59.4 \mathrm{~kb}$ apart (ss86284409: $G>A$ at 111,623,092 bp and ss86341066:A $>C$ at 111,682,510 bp) were associated with MAP tissue infection $(P<0.05$; Table 2 ). These 2 SNP were in strong linkage disequilibrium (LD) with each other $\left(\mathrm{r}^{2}=0.784, \mathrm{D}^{\prime}=0.99\right)$. The locus ss86341066 provided the strongest evidence for association $(P=0.0001)$ with almost a 2 -fold difference in the allele frequency between the cases $(0.26)$ and the controls (0.5). This was also the locus previously reported as being associated with MAP tissue infection (Settles et al., 2009; Neibergs et al., 2010). Of the 22
SNP evaluated on BTA3, 6 loci (ss86284409:G $>A$, rs43364339:A > C, rs43364342:A > T, rs43336322:A > $G$, ss86341066:A $>C$, and rs43363215:A > G) comprised a single haplotype block that spanned a $70-\mathrm{kb}$ region. This haplotype (ACTGCG) was associated $(P$ $=0.0003)$ with MAP tissue infection because it was found at higher frequency (0.64) in animals that were MAP tissue positive than in animals that were MAP tissue negative (0.46; Table 2). This haplotype provided supporting evidence that a causative mutation for MAP tissue infection resides in this region of BTA3, but it did not provide stronger evidence than the association detected with ss86341066: $A>C$ alone $(P=$ 0.0001). The systematic elimination of SNP from the most significant haplotype block demonstrated that the 
Table 2. Loci associated with Mycobacterium avium ssp. paratuberculosis (MAP) tissue infection on BTA3

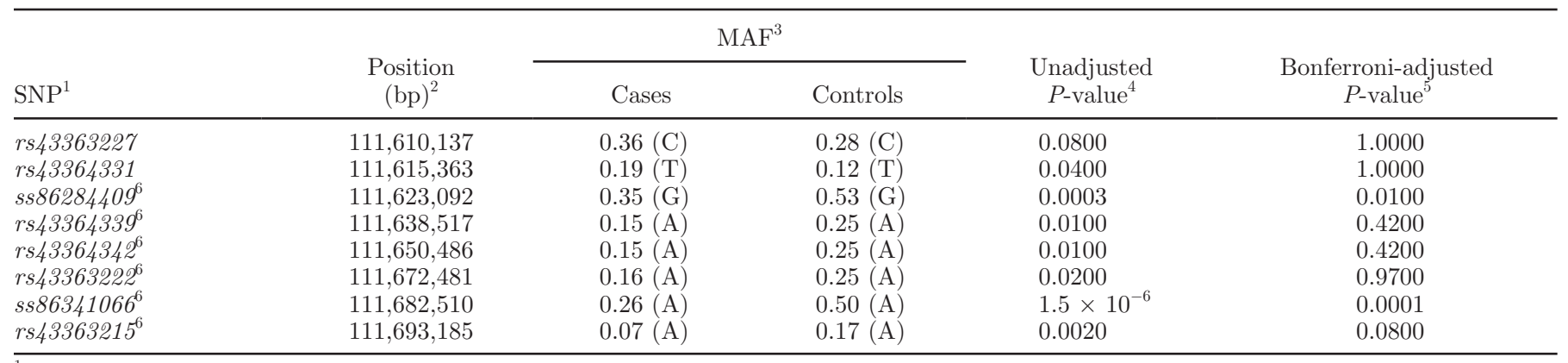

${ }^{1}$ GenBank accession number for the SNP (http://www.ncbi.nlm.nih.gov/projects/SNP).

${ }^{2}$ Location of the SNP on chromosome 3 based on Btau_4.0 (Liu et al., 2009).

${ }^{3}$ Case: variant nucleotide (listed in parentheses) that represents the allele with the lowest frequency (minor allele frequency or MAF) in animals that are MAP tissue positive, regardless of whether they were shedding MAP in the feces; Control: variant nucleotide (listed in parentheses) that represents the allele with the lowest frequency (minor allele frequency or MAF) in animals that are MAP tissue negative, regardless of whether they were shedding MAP in the feces.

${ }^{4}$ Chi-squared asymptotic $P$-value before Bonferroni adjustment for multiple testing.

${ }^{5}$ Chi-squared asymptotic $P$-value after Bonferroni adjustment for multiple testing.

${ }^{6} \mathrm{SNP}$ that comprise the haplotype block associated with MAP tissue infection $(P=0.0003)$.

elimination of ss86284409 from the haplotype analysis improved the significance of the association $\left(3 \times 10^{-4}\right.$ to $\left.7.8 \times 10^{-6}\right)$. Additional removal of $r s 43364339$ did not alter the significance of the haplotype $\left(P=8 \times 10^{-6}\right)$. Additional removal of rs43364342 and rs43363222 improved the significance $\left(P=1.55 \times 10^{-6}\right)$; moreover, the use of only ss86341066 and rs433623215 provided the strongest evidence $\left(P=1.55 \times 10^{-6}\right)$ for an association with tissue infection. These 2 SNP redefine the region of $235 \mathrm{~kb}$ to a region of $10.6 \mathrm{~kb}$ that most likely harbors the functional mutation responsible for the association of MAP tissue infection on BTA3.

Within the 194-kb region tested on BTA15, tolerance to Johne's disease was associated $(P<0.05)$ with 2 loci that were located $22.9 \mathrm{~kb}$ apart (rs41745722: $T>C$ at 21,228,547 bp and rs41748392: $G>A$ at 21,251,461 bp; Table 3). Two SNP, rs41745722 $(P=0.001)$ and rs41748392 $\left(P=3.4 \times 10^{-5}\right)$, were associated with tolerance to Johne's disease in the same region that previously provided strong evidence for an association

Table 3. Loci associated with tolerance to Johne's disease on BTA15

\begin{tabular}{|c|c|c|c|c|}
\hline $\mathrm{SNP}^{1}$ & $\begin{array}{l}\text { Position } \\
(\mathrm{bp})^{2}\end{array}$ & $\mathrm{MAF}^{3}$ & $\begin{array}{l}\text { Unadjusted } \\
P \text {-value }\end{array}$ & $\begin{array}{c}\text { Bonferroni-adjusted } \\
P \text {-value }\end{array}$ \\
\hline rs41746737 & $21,224,197$ & $0.15(\mathrm{C})$ & 0.030 & 1.00 \\
\hline$r s 41745722^{6}$ & $21,228,547$ & $0.37(\mathrm{~T})$ & $3.7 \times 10^{-5}$ & $1.0 \times 10^{-3}$ \\
\hline$r_{4} 1745716^{6}$ & $21,235,084$ & $0.15(\mathrm{~T})$ & 0.030 & 1.00 \\
\hline rs41748392 & $21,251,461$ & $0.44(\mathrm{G})$ & $6.38 \times 10^{-7}$ & $3.4 \times 10^{-5}$ \\
\hline$r s 4174840^{26}$ & $21,253,408$ & $0.09(\mathrm{~T})$ & 0.490 & 1.00 \\
\hline rs41748401 & $21,257,974$ & $0.15(\mathrm{~T})$ & 0.030 & 1.00 \\
\hline$r s 41748400^{6}$ & $21,260,261$ & $0.15(\mathrm{C})$ & 0.030 & 1.00 \\
\hline rs41748395 & $21,262,642$ & $0.28(\mathrm{~T})$ & 0.020 & 1.00 \\
\hline$r s 41748410^{6}$ & $21,263,976$ & $0.32(\mathrm{~T})$ & 0.014 & 0.75 \\
\hline$r s 41748412^{6}$ & $21,270,896$ & $0.32(\mathrm{~A})$ & 0.018 & 0.97 \\
\hline rs41749247 & $21,276,876$ & $0.14(\mathrm{~T})$ & 0.030 & 1.00 \\
\hline rs41749241 & $21,280,720$ & $0.14(\mathrm{G})$ & 0.020 & 1.00 \\
\hline rs41749235 & $21,283,665$ & $0.15(\mathrm{~T})$ & 0.050 & 1.00 \\
\hline rs41748422 & $21,288,468$ & $0.34(\mathrm{~T})$ & 0.070 & 1.00 \\
\hline rs41748420 & $21,289,813$ & $0.15(\mathrm{G})$ & 0.050 & 1.00 \\
\hline$r s 41748415$ & $21,295,290$ & $0.32(\mathrm{C})$ & 0.030 & 1.00 \\
\hline
\end{tabular}

${ }^{1}$ GenBank accession number for each SNP (http://www.ncbi.nlm.nih.gov/projects/SNP).

${ }^{2}$ Location of the SNP on chromosome 15 based on Btau_4.0 (Liu et al., 2009).

${ }^{3}$ Variant nucleotide (listed in parentheses) that represents the allele with the lowest frequency (minor allele frequency, MAF) in animals evaluated for tolerance.

${ }^{4}$ Wald test asymptotic $P$-value before Bonferroni adjustment for multiple testing.

${ }^{5}$ Wald test asymptotic $P$-value after Bonferroni adjustment for multiple testing.

${ }^{6} \mathrm{SNP}$ that comprise the haplotype block associated with tolerance $\left(P=8.09 \times 10^{-6}\right)$. 
(Zanella et al., 2011). Both of these SNP are in strong $\mathrm{LD}\left(\mathrm{r}^{2}=0.417\right.$ and $\left.\mathrm{D}^{\prime}=0.914\right)$.

A 42-kb haplotype block (TCACCGCCG), composed of 9 SNP including rs41745722 and rs41748392, was associated $\left(P=8.09 \times 10^{-6}\right)$ with tolerance to Johne's disease on BTA15 (Table 3). The haplotype analysis on BTA15 did provide stronger evidence of an association than the individual loci identified as being associated with tolerance to Johne's disease. This reduced the region of interest from 194 to $42 \mathrm{~kb}$. Methodically eliminating combinations of these 9 SNP by backward elimination provided an additional narrowing of the region associated with tolerance to Johne's disease. The SNP providing the most evidence for an association using this approach were rs4174522, rs41745716, and $r 541748392\left(P=5.5 \times 10^{-6}\right)$ that span a $22.9-\mathrm{kb}$ region of BTA15. As rs4174522 and rs41748392 were in high linkage disequilibrium $\left(\mathrm{D}^{\prime}=0.914\right)$, these results suggest that the $6.5-\mathrm{kb}$ region between $r s 4174522$ and rs41745716 is the most likely to harbor a mutation associated with tolerance to Johne's disease.

Loci previously identified as associated with MAP tissue infection and tolerance to Johne's disease in a whole-genome association analysis were further characterized in the current study (Settles et al., 2009; Zanella et al., 2011). The objective of this study was to refine these loci to narrow the region to explore for a mutation associated with MAP tissue infection and tolerance to Johne's disease. The locus for MAP tissue infection was refined to 2 SNP $10.6 \mathrm{~kb}$ apart on BTA3 and the locus for tolerance to Johne's disease to 3 SNP, 2 of which are in high $\mathrm{LD}$, further refining the region to $6.5 \mathrm{~kb}$ on BTA15.

It is possible that the 2 narrow regions identified in this study do not host the functional mutations for these associations. This could occur if the 2 SNP that define these regions were in $\mathrm{LD}$ with the functional mutation but were positioned outside the regions targeted in this study. If the initial genome-wide association studies (Settles et al., 2009; Zanella et al., 2011) had had perfect placement of SNP in relationship to the changes in LD throughout the genome, then the identification of LD with ss86341066 and rs433623215on BTA3 and rs4174522 and rs41745716 on BTA15 and other genomic regions would have been detected. However, it is known that the SNP placement in the Illumina BovineSNP50 BeadChip is imperfect and so the possibility exists that the SNP that bound the 10.6-kb and $6.5-\mathrm{kb}$ regions may not represent the boundaries of the location of the functional mutations but merely represent a region in $\mathrm{LD}$ with the functional mutation. Resequencing of the DNA in this region along with functional studies will be needed to determine if these regions contain the functional mutations responsible for the associations with Johne's disease.

Positional candidate genes were not identified immediately within the refined regions associated with MAP tissue infection on BTA3 or tolerance to Johne's disease on BTA15. However, the region associated with MAP tissue infection on BTA3 is highly conserved between human, chimpanzee, dog, and cow, harbors several different regulatory elements, and is adjacent $(30 \mathrm{~kb})$ to endothelin-2 (EDN2) (National Center for Biotechnology Information, 2010). The region associated with tolerance to Johne's disease on BTA15 is partially conserved among human, dog, and cow, has not been shown to contain regulatory elements, but is $19 \mathrm{~kb}$ from guanine nucleotide binding protein ( $\mathrm{G}$ protein) $\alpha 12$ (GNA12) (National Center for Biotechnology Information, 2010).

In conclusion, this study has refined a locus for MAP tissue infection and a locus for tolerance to Johne's disease. Further investigation of these loci for the mutations responsible for these associations will contribute to our understanding of the mechanisms underlying MAP tissue infection and tolerance to Johne's disease and provide resources for the selection of cattle less susceptible to Johne's disease.

\section{REFERENCES}

Buergelt, C. D., C. Hall, K. McEntee, and J. R. Duncan. 1978. Pathological evaluation of paratuberculosis in naturally infected cattle. Vet. Pathol. 15:196-207.

Gonzalez, J., M. V. Geijo, C. Garcia-Pariente, A. Verna, J. M. Corpa, L. E. Reyes, M. C. Ferreras, R. A. Juste, J. F. Garcia Marin, and V. Perez. 2005. Histopathological classification of lesions associated with natural paratuberculosis infection in cattle. J. Comp. Pathol. 133:184-196.

Johnson-Ifearulundu, Y. J., J. B. Kaneene, D. J. Sprecher, J. C. Gardiner, and J. W. Lloyd. 2000. The effect of subclinical Mycobacterium paratuberculosis infection on days open in Michigan, USA, dairy cows. Prev. Vet. Med. 46:171-181.

Liu, Y., X. Qin, X. Z. Song, H. Jiang, Y. Shen, K. J. Durbin, S. Lien, M. P. Kent, M. Sodeland, Y. Ren, L. Zhang, E. Sodergren, P. Havlak, K. C. Worley, G. M. Weinstock, and R. A. Gibbs. 2009. Bos taurus genome assembly. BMC Genomics 10:180.

NAHMS (National Animal Health Monitoring System). 1997. Johne's disease on U.S. dairy operations. \#N245.1097. USDA:APHIS:VS, CEAH, Fort Collins, CO.

National Center for Biotechnology Information. 2010. Database SNP. Accessed Feb. 2, 2010. http://www.ncbi.nlm.nih.gov/projects/ $\mathrm{SNP} /$.

Neibergs, H. L., M. L. Settles, R. H. Whitlock, and J. F. Taylor. 2010. GSEA-SNP identifies genes associated with Johne's disease in cattle. Mamm. Genome 21:419-425.

Nordlund, K. V., W. J. Goodger, J. Pelletier, and M. T. Collins. 1996. Associations between subclinical paratuberculosis and milk production, milk components, and somatic cell counts in dairy herds. J. Am. Vet. Med. Assoc. 208:1872-1876.

Pradhan, A. K., J. S. Van Kessel, J. S. Karns, D. R. Wolfgang, E. Hovingh, K. A. Nelen, J. M. Smith, R. H. Whitlock, T. Fyock, S. Ladely, P. J. Fedorka-Cray, and Y. H. Schukken. 2009. Dynamics of endemic infectious diseases of animal and human importance 
on three dairy herds in the northeastern United States. J. Dairy Sci. 92:1811-1825.

Purcell, S., B. Neale, K. Todd-Brown, L. Thomas, M. A. Ferreira, D. Bender, J. Maller, P. Sklar, P. I. de Bakker, M. J. Daly, and P. C. Sham. 2007. PLINK: A tool set for whole-genome association and population-based linkage analyses. Am. J. Hum. Genet. $81: 559-575$.

Raberg, L., D. Sim, and A. F. Read. 2007. Disentangling genetic variation for resistance and tolerance to infectious diseases in animals. Science 318:812-814.

Seitz, S. E., L. E. Heider, W. D. Heuston, S. Bech-Nielsen, D. M. Rings, and L. Spangler. 1989. Bovine fetal infection with Mycobacterium paratuberculosis. J. Am. Vet. Med. Assoc. 194:1423-1426.

Settles, M., R. Zanella, S. D. McKay, R. D. Schnabel, J. F. Taylor, R. Whitlock, Y. Schukken, J. S. Van Kessel, J. M. Smith, and H. Neibergs. 2009. A whole genome association analysis identifies loci associated with Mycobacterium avium ssp. paratuberculosis infection status in US Holstein cattle. Anim. Genet. 40:655-662.

Stecher, B., and W. D. Hardt. 2008. The role of microbiota in infectious disease. Trends Microbiol. 16:107-114.

Sweeney, R. W., R. H. Whitlock, A. N. Hamir, A. E. Rosenberger, and S. A. Herr. 1992a. Isolation of Mycobacterium paratuberculosis after oral inoculation in uninfected cattle. Am. J. Vet. Res. $53: 1312-1314$
Sweeney, R. W., R. H. Whitlock, and A. E. Rosenberger. 1992b. Mycobacterium paratuberculosis isolated from fetuses of infected cows not manifesting signs of the disease. Am. J. Vet. Res. 53:477-480.

USDA. 2008. Johne's disease on U.S. dairies 1991-2007. \#N521.0408 National Animal Health Monitoring System. USDA:APHIS:VS, CEAH, Fort Collins, CO.

Whitlock, R. H., A. E. Rosenberger, R. W. Sweeney, and P. A. Spencer. 1996. Distribution of M. paratuberculosis in tissues of cattle from herds infected with Johne's disease. Pages 168-174 in Fifth International Colloquium on Paratuberculosis International Association for Paratuberculosis, Madison, WI. R. J. Chiodini, M. E. Hines, and M. T. Collins, ed. International Association for Paratuberculosis Inc., Madison, WI.

Whitlock, R. H., S. J. Wells, R. W. Sweeney, and J. Van Tiem. 2000. ELISA and fecal culture for paratuberculosis (Johne's disease): Sensitivity and specificity of each method. Vet. Microbiol. 77:387-398.

Zanella, R., M. L. Settles, S. D. McKay, R. Schnabel, J. Taylor, R. H. Whitlock, Y. Schukken, J. S. Van Kessel, J. M. Smith, and H. L. Neibergs. 2011. Identification of loci associated with tolerance to Johne's disease in Holstein cattle. Anim. Genet. 42:28-38. 